\title{
Making Sense of Resistance: How Adult Immigrant Students Pursue Agency Through Identity Work in Higher Educational Contexts
}

\author{
Emily K. Suh \& Shawna Shapiro
}

Student resistance in the language/literacy classroom has been an important focus of research in TESOL and applied linguistics. This article examines resistance by two adult-arrival immigrant students in a developmental literacy classroom, drawing from a larger ethnographic case study focused on students' transition into community college. The students' behaviours seemed puzzling or self-defeating to some college personnel, but when viewed through the theoretical framework of identity work, they can be read as attempts to counteract institutional marginalization. Findings from this analysis illustrate how an understanding of the histories, identities, and investments of adult immigrant learners can help educators respond to "difficult" moments in the classroom and beyond. This study has several implications for higher education practitioners: First, we must question our initial assumptions about student behaviours, so that we interpret those behaviours accurately. Second, we must be explicit about the norms of the academic culture, so that students can more effectively enact their desired identities and display symbolic capital in college courses. Finally, we must build curricula, policies, and pedagogies that are more inclusive and relevant for adult immigrant learners. These findings add to scholarly conversations about immigrant students' funds of knowledge and agency enactment within postsecondary education.

La résistance des étudiants dans la salle de classe de langue ou de littératie est devenue un point focal de la recherche en TESOL et en linguistique appliquée. Cet article examine la résistance de deux étudiants immigrants adultes récemment arrivés dans une classe de développement de la littératie, en s'appuyant sur une étude de cas ethnographique plus large qui se concentre sur la transition des étudiants vers un collège communautaire. Aux yeux de certains membres du personnel du collège, le comportement des étudiants semblait déroutant ou semblait nuire à leur réussite; cependant, quand on utilisait la perspective du cadre de travail identitaire, le comportement peut se comprendre comme des tentatives de contrecarrer la marginalisation institutionnelle. Les résultats de cette analyse illustrent comment la compréhension des histoires, des identités et des investissements des étudiants immigrants adultes peut aider les éducateurs à répondre aux moments "difficiles " dans la salle de classe et au-delà. Cette étude a plusieurs implications pour les praticiens de l'enseignement supérieur. Premièrement, nous devons remettre en question nos suppositions premières 
à propos du comportement des étudiants de façon à l'interpréter correctement. Deuxièmement, nous devons expliquer clairement les normes de la culture universitaire, afin que les étudiants puissent entrer plus efficacement dans leur identité recherchée et montrer leur capital symbolique dans les cours collégiaux. Pour conclure, nous devons créer des programmes, des politiques et des pédagogies qui soient plus inclusives et plus pertinentes pour les apprenants immigrants adultes. Ces résultats s'ajoutent aux conversations universitaires sur le fonds de connaissances des étudiants immigrants et leur capacité d'agir au sein de l'enseignement postsecondaire.

Key words: adult-arrival immigrants, resistance, agency, postsecondary education

Student resistance has become an important focus of inquiry in TESOLparticularly in English for academic purposes contexts. Extant scholarship includes examples of how multilingual/English for speakers of other languages (ESOL) students "push back" against inaccurate or marginalizing institutional labels (e.g., Harklau, 2000; Waterstone, 2008), irrelevant or unchallenging curricula (e.g., Canagarajah, 1993; McKay \& Wong, 1996), and unfair or inappropriate expectations for classroom behaviour (e.g., Norton \& Toohey, 2011; White, 2011).

In many cases, student resistance stems from cultural mismatch or miscommunication. Behaviours that are perceived as resistance may reflect unfamiliarity with the norms of particular academic cultures (e.g., Ferris \& Tagg, 1996; Pennycook, 1996). Although the frame of "culture clash" can be useful (e.g., Song, 2016), it sometimes flattens accounts of student behaviours, overlooking important complexities (Ngo, 2008). As McKay and Wong (1996) explained, students are always negotiating "dynamic, sometimes contradictory, multiple identities" (p. 577), and student choices or behaviours that run counter to instructor (or researcher) expectations can sometimes be understood as performing certain kinds of "identity work" (Norton \& Toohey, 2011; Parks, 2000). Drawing on prior work by Bonny Peirce Norton (1995), McKay and Wong (1996) argued that by attending to students' complex, social identities, we can better understand why "some learners seem to act counter-productively, using strategies that subvert or oppose the language expectations of the situation" (p. 578; see also Kim \& Duff, 2012).

This link between resistant student behaviours and identity performance has been taken up in a number of studies, as will be discussed further in our literature review. The present study contributes to this work in three ways: first, we add a focus on academic experience and not just linguistic behaviours (e.g., language choice or performance); second, we offer detailed analysis of what happens when resistance as identity work is (mis)read by 
instructors; finally, we examine resistance in academic spaces beyond the classroom, such as writing and learning centers.

This article draws from an ethnographic case study focused on adult immigrant learners (Suh, 2017) in a community college setting. Our central research questions are as follows: What forms of resistance do adult immigrant learners employ in developmental literacy classes? What sorts of identity work might underlie this resistance? Guided by these questions, we explore examples of resistance on the part of two students-examples that seemed puzzling or even self-defeating to college personnel. We show how these student behaviours might be read not as distancing or disengagement but as attempts to (re)invest in the academic identities the students see as central to their educational success.

\section{Literature Review}

\section{Contextualizing Resistance as Identity Work}

We define resistance as students' enactment of agency for the purpose of challenging undesirable assigned social roles or asserting claims to certain forms of power. In English language learning contexts, these behaviours have often been "read" as resistant because they may diverge from expected norms for academic participation, and are therefore seen as potentially harmful to the student and/or to the academic community (Carter \& Hendrichsen, 2015; Gartman, 2016). Resistance is linked not only to identity, as noted earlier, but also to agency. As explained by Norton (2013), "While larger structural constraints and classroom practices might position learners in undesirable ways, learners, with human agency, can resist these positions in innovative and unexpected ways" (p. 21; see also Shapiro \& MacDonald, 2017; Liu \& Tannacito, 2013; Winchester, 2013).

Resistance in academic settings can take a number of forms. Students may appear disengaged or "off task" in the classroom (e.g., Norton \& Toohey, 2011). They may refuse to complete particular assignments or may make linguistic or rhetorical choices that subvert expectations of the instructor, genre, or discipline (e.g., Leki, 1995; Liu \& Tannacito, 2013; McKay \& Wong, 1996; Parks, 2000). Students may also resist labels that they view as problematic, such as "English as second language" (ESL) or "non-native speaker" (e.g., Ortmeier-Hooper, 2008; Waterstone, 2008), or may make decisions against the advice of instructors or administrators, including withdrawing from classes (e.g., Norton, 2013).

To understand how these behaviours might serve as identity work, one must consider which identities immigrant students tend to resist (or foreground) in academic settings. First, students may resist instruction that overlooks their multilingual and/or multicultural identities. In a study by 
Canagarajah (1993), for example, Tamil-speaking students in an English for specific purposes class wrote graffiti in their U.S. English textbooks, foregrounding instead their rural, Tamil, and activist identities as a way to resist discourses that positioned them as powerless. Similarly, McKay and Wong (1996) showed how high school students' use of Mandarin in an ESL class countered model minority discourses and asserted students' identities as Chinese linguistic and cultural insiders.

Resistance can also be a way to assert ownership of the target languagei.e., to push back against the identity of non-native speaker or language learner. This often manifests in students' negative responses to the "ESL" label, which they see as invoking assumptions of linguistic deficit, academic underperformance, and outsider status (Harklau 2000; see also Shapiro, 2014; Waterstone, 2008). Harklau (2000) documented how immigrant-background students who had been successful in U.S. high schools were repositioned as foreigners and/or newcomers in community college settings. The students resisted that repositioning by appearing disengaged in ESOL classes (which they had been placed into involuntarily) and expressing reluctance about using other academic supports. The ESOL instructors in turn interpreted these behaviours as "lack of cooperation" or "rudeness" (p. 54). As a result, learners who had been seen as "good students" in high school were now viewed and treated as "bad" in college. Ortmeier-Hooper (2008) discussed a similar case of a student named Sergej, whose rejection of the "ESL" identity caused him to avoid seeking help from his first language (L1) composition instructor, as well as from support resources like the writing center-even though many students (even "native" English speakers) also made use of these supports (see Kim \& Duff [2012], for case studies with similar dynamics).

For adult immigrant learners, there are additional identities that can underlie resistant behaviours. Adult learners may feel alienated by classroom curricula and pedagogies that obscure their past schooling experience and/or that overlook their imagined educational futures. For example, Norton (2013) described how Katarina, a highly educated teacher from Poland, resisted ESL class expectations such as memorizing lengthy and decontextualized vocabulary lists, because they made her feel "like a student in first grade" (p. 177). Insulted that her instructor positioned her as a newcomer, Katarina eventually dropped the class. Waterstone (2008) described a similar case in which an undergraduate named Susan rejected some of the feedback and suggestions from a writing center consultant, in part because she felt that the consultant saw her as an "ESL student" and overlooked her other identities as an English major and former English tutor. This resistance can take place on a collective level as well: Curry (2001) presented a case study of a developmental literacy class at a community college that included many students with high levels of prior higher education (undergraduate and even graduate school) in their countries of origin. These students felt that the literacy curriculum, focused largely on isolated grammar instruction, did not recognize or build 
upon these experiences; nor did it take into account their goals in pursuing further education. They resisted this curriculum through low visible affect and distracted behaviours, as well as frequent absences.

Civic and/or professional identities can also inform learners' resistance in the language classroom, often serving as a counterpoint to the identity of immigrant or language learner that is dominant in most educational research (Miller, 2010; Warriner, 2004). Katarina, a student referenced earlier, felt that her instructor's positioning of students as linguistic and cultural outsiders left little room to recognize the ways she already used English effectively in communicating with her child's school and in pursuing her career goals (Norton, 2013). Katarina ultimately dropped her ESL class after the instructor said Katarina's English was not good enough to enroll in a computer class that Katarina felt aligned better with her professional trajectory. Similarly, Harklau (2013) discussed a student named Izzie, who framed her decision to work full-time rather than attending college as a liberatory feminist act, contradicting prevalent narratives of what success looks like for Latina immigrants. This sort of identity work takes place in research interviews with adult immigrant learners as well (Miller, 2010; Warriner, 2004).

It is important for scholars and practitioners to understand resistance as identity work in part because this understanding might shape how they choose to respond. As Liu and Tannacito (2013) explained, "When students fail to conform to teaching instruction, their nonparticipation or resistance tends to be categorized from the teacher's point of view as 'problematic'" (p. 369). With a more nuanced reading of the identity work at play, instructors can begin to see resistance not as evidence of student passivity or disinterest, but as an opening for conversation (Dumas, 2008; Liu \& Tannacito, 2013; Parks, 2000). In most of the cases noted above, resistance manifested as a form of disengagement from the academic community. However, the two cases we present below are less clear-cut, involving students who engaged in what they saw as good student behaviours, in an attempt to legitimize or reinvest in their participation within the academy. Thus, resistance in this study was a form of identity work that students employed in the hopes of increasing their agency within higher education.

\section{Methodology}

In order to explore how two learners, Labiba and $\mathrm{Al}$ Share (all names are pseudonyms), engaged in resistance as identity work, we reexamined data from a larger, multiple case study (Merriam, 2009) of adult immigrant learners' college entry experiences (Suh, 2018). We aimed for what Merriam (1998) characterizes as "an intensive, holistic description and analysis of a bounded phenomenon" (p. 27). The original study included six adult-arrival immigrants (Rumbaut, 2004) transitioning from adult ESL into postsecondary developmental literacy courses at a midsized community college in the 
Midwest. At this particular college, ESL and developmental literacy were distinct both structurally and pedagogically, with the latter designed with L1 (vs. second language [L2]) learners in mind, despite the high numbers of adult immigrant students in both sets of courses (see Paulson \& Holschuh, 2018 for more on the prevalence of this set up). The ESL courses, offered at 10 levels, ranged from basic/ "survival" English to more of an English for academic purposes focus, while the developmental literacy curriculum was a two-course sequence focused on preparing students for the reading and writing tasks expected of college-level disciplinary courses.

Both Labiba and Al Share entered the college via the noncredit ESL sequence. Both learners enrolled in sections of a developmental literacy course with the same instructor, but in different terms. Before transitioning into credit-bearing classes, students were required to take a placement exam. Many of these students were placed initially into (noncredit) ESL courses, but-similar to Harklau's (2000) findings-resisted this placement, feeling that the credit-bearing developmental literacy courses were better aligned with their self-identification as college-ready rather than ESL students. After participating in a noncredit study lab that helped to improve their placement exam scores, a number of students-including Labiba and Al Share-were placed into the first of two credit-bearing developmental literacy courses. These courses were taught by faculty with (L1) English backgrounds trained in English composition/rhetoric but not in TESOL or applied linguistics, who largely reported feeling ill-prepared to support this group of learners. (This concern has been noted by developmental literacy and TESOL scholars as well-e.g., de Kleine \& Lawton, 2015). Hence, these two students were somewhat marginalized even at the start of the quarter, working with an instructor who questioned whether they belonged in developmental literacy in the first place. Yet they were also highly aspirational, as indicated by their decision to bypass the ESL sequence in order to enroll in credit-bearing courses.

The first author was employed at the college during the learners' first term in their developmental literacy courses. She conducted interviews with students, faculty, and staff, as well as observations of the learners in their developmental literacy classes, in the writing center, and at their preferred places of study. The first author maintained validity through the evidence chain and comparison, repetition, and triangulation across the data set (Yin, 2014) and sought out peer examination (Merriam, 2009) through member checking with a developmental literacy instructor who also worked in the writing center. After the original study's completion, the second joined for a reanalysis of the data. We choose Labiba and Al Share as a theoretical sample (Merriam, 1998) to further investigate the phenomenon of resistance. Although occasional resistance had been observed in the other four cases, these two cases illustrate most saliently the problems that emerge when resistance is (mis)interpreted by instructors and other staff. We reanalyzed these two cases, 
using a constant comparative method, beginning with category construction (e.g., asserting an alternative identity), followed by comparing subsequent pieces of data to other observation notes or verbatim speech from transcripts within each category (e.g., English language expert or persevering refugee). The final step of analysis was to identify interrelationships among the categories, focusing on the themes of learner resistance and identity enactment.

\section{Findings}

In both of these case studies, we found examples of resistance regarding classroom behaviour, assignment completion, and use of support resources. In Labiba's case, the identity of "survivor" likely informed her behaviours in the classroom and the learning center, some of which were read as inappropriate. In the case of Al Share, the identity of "intellectual" fueled his resistance to course materials and activities that he saw as below his scholarly and linguistic capabilities.

\section{Labiba}

Labiba was a 60-year-old woman who fled Afghanistan at the start of the Soviet-Afghan War in 1979. After spending her childhood abroad in Pakistan, Iraq, and Iran, Labiba immigrated with her own children to the United States as a single mother, in part to pursue higher education. During their second meeting, Labiba explained to the first author how her past shaped her decision in her 50 s to pursue an education:

They [Mujahideen] broke my school. They killed my family. They don't let me my dream [of an education] come true. After I went to like Iran, Pakistan, I came to here [the United States], like something my heart was bothering me...said, "Wow, you know what, war take everything, but war not take the small thing from my head." I said, "I have to use this one for my school."

Being and being seen as someone who persists despite all odds, both personally and academically, was central to Labiba's identity. One way she conveyed this identity was by frequently retelling stories about her lifetime of struggle-even to strangers she had just met. Nearly everyone who worked with Labiba at City Community College had heard multiple stories about her difficult past, and many expressed respect and appreciation for these stories. For example, Nick, a tutor in the Writing Center who worked frequently with Labiba, told the first author:

It was always very easy to get her to talk about her life in Afghanistan, and all she had gone through there [...] And I spent a lot of time kind of validating her experience and that she was brave to be writing these things, that it was good, and therapeutic for her, 
and I don't know if that [assumption about the therapeutic benefits] was really true, but it - there was a lot of encouragement, a lot of praise.

Nick justified spending this time not only because he cared about Labiba, but also because he felt that talking about these stories "usually fed nicely into what she was being asked to do [in class] with its focus on narrative work."

Tutors at the Bridging Lab, who work with students on English and mathematics skills, had also heard many of Labiba's stories. Some tutors saw a link between her personal persistence and her academic determination. As Rachel, a Lab advisor, noted to the first author, "You see her here every day at the computer doing the work, yet despite everything that she's been through, she is such a happy person wanting to learn." Referencing Labiba's ability to persist in her personal life, the advisor described Labiba as having "the will and the determination" to succeed in college. Indeed, Labiba's presence in the developmental literacy course was itself indicative of persistence, since she had skipped over courses in the ESL sequence, as noted earlier.

Yet there were times when Labiba chose to perform this identity in ways that some college faculty and staff felt were inappropriate. In a midterm session of the developmental literacy course in which students were planning to present book reports, the first author observed Labiba's multiple interruptions, including during a lecture by her instructor (Anne) and during a classmate's presentation. Each time, Labiba approached the lectern in order to ask for assistance. After Anne's second refusal to provide immediate assistance,

Labiba returned to her seat with reluctance, loudly expressing her frustration with her instructor's refusal to assist her. When Anne called for additional students to present, Labiba quickly volunteered. Although her classmates largely ignored Labiba and talked amongst themselves as Anne helped her pull up her presentation, Labiba became increasingly frustrated. "What?" Labiba turned to address her classmates directly, "You know what, my computer just two years old. I don't know about this one. You don't have to laugh at me." One of the girls in the group piped up, "We're not laughing at you." (Observation Notes)

Despite Anne's reminder at the beginning of the class about the time requirements and the purpose of the presentation as outlined in a class handout, Labiba chose instead to project photographs of her family in Afghanistan. She explained that she had chosen a book, "about WWII about the man named Hitler" because it reminded her of her experiences in Afghanistan during the war, but she did not provide the book's title or author. Instead, Labiba compared her experiences with those of the story's 
main characters, a Jewish family who had been sent to a concentration camp. She explained that her experience with war "is exactly the same [as that of the family] ... even you lose your friend, your family, your everything. The pain was exactly the same." After briefly describing events in the book, Labiba shared anecdotes about her family's persistence through war, homelessness, and immigration. Her "10-minute" presentation lasted nearly 30 minutes, but-perhaps in an effort to honour Labiba's courage in sharing-Anne never interrupted Labiba or asked her to conclude her personal narrative.

After class, Anne told the first author that this was not the first instance in which Labiba seemed to disregard participation rules or assignment guidelines. She noted that Labiba's interruptions could be as frequent as "five or six times in a class in the first few days... [she] would just get up in the middle of something and come ask me something that was totally unrelated." Anne felt conflicted about directly addressing these behaviours, in part because she felt they stemmed from cultural misunderstanding and lack of preparation- "ESL"-type issues she thought could only be addressed with time and experience. Six weeks into the class, Anne noted "She's gotten a little bit better about it," but the behaviours were still frequent; they demonstrated, in Anne's view, a lack of awareness of others, as well as limited academic preparation: "I don't think she sees other people," Anne concluded, adding that "She really doesn't know what it means to be in an American classroom." Anne admitted that she sometimes wondered if Labiba should have remained in ESL classes rather than developmental literacy.

Labiba repeated some of these same behaviours in other academic spaces. For example, in the Bridging Lab, she frequently interrupted the math tutor during his explanations of material. As she described to the first author, "I just walk by the blackboard, say [to the tutor], 'What is this?' He love it" [sic]. Labiba rationalized her behaviour with the explanation that the tutor would not want her to sit in silent confusion and that he was in fact impressed with her courage in interrupting him.

Labiba's identity as "one who persists" also manifested in the way she made use of other academic support resources. Labiba visited the Writing Center on a daily basis - not only to get feedback and suggestions for writing assignments, but also to ask questions as she reviewed her class notes, taken in Arabic, Pashto, and English. However, many writing tutors were uncomfortable with the amount of guidance and time Labiba expected from them. As explained by David, a writing tutor with whom Labiba worked almost daily, "With non-directive tutoring [the style in which the tutors were trained], the idea is you are supposed to make the student take ownership of their own paper." Hence, Labiba's use of the Writing Center, which she saw as an indicator of academic persistence, was read, ironically, by some tutors as unwillingness to work independently-and as contrary to the center's philosophy. Labiba exerted her persistence further in attempting to find the tutors who would give her the type of assistance she was looking for: "[She] 
must have worked with every single writing tutor at least once," explained David, "and then she would find the ones that she felt like would give her more help and avoided the ones who adhered to the more strict non-directive [approach]."

As was the case in the developmental literacy course, staff in the Bridging Lab and Writing Center interpreted Labiba's behaviours largely as issues with cultural and academic adjustment, and they assumed that the behaviours would improve over time. This interpretation, plus a fear that confronting Labiba too directly might retrigger past trauma, led instructors and other staff to tread carefully: they ignored or gently redirected the behaviours. Amongst themselves, however, they became quite concerned-especially when they did not see the changes they were expecting. Nick recalled the frequency with which tutors discussed Labiba's struggles: "One of us opined during one of these discussions that she has PTSD basically and that when she is stressed, she can't learn. And she is stressed all of the time." At one point, some personnel even discussed privately whether Labiba was experiencing a nervous breakdown.

In essence, Labiba's greatest strengths - her motivation and drive to succeed-came to be interpreted as a liability, as instructors and other staff saw her not just as determined but as potentially "traumatized." Contributing to this narrative was the fact that Labiba came to view personnel who did not give her what she wanted as another obstacle to overcome. In observation notes, the first author wrote: "[Labiba] kept referring to tutors and lab advisors as 'bad men' - the phrase she used to describe the Mujahideen who killed her cousin." An alarming cycle emerged whereby Labiba resented college personnel for their friendly concern and blamed them for her academic struggles. Ironically, as others rejected Labiba's participation efforts (i.e., by redirecting her behaviours) and feared her re-traumatization, Labiba increasingly and vocally claimed her identity as an overcoming refugee, who now also persisted despite the college.

\section{Al Share}

Al Share was a 70-year-old published author and political activist when he transitioned from adult ESL into developmental literacy classes at City Community College. Al Share had left his small Sudanese farming village at a young age to study in the city, later relocating to Egypt, where he finished high school and college, started a family, and worked full-time. During this time, Al Share also studied English abroad in England, began a master's degree in communication, and gained an international reputation for his political writings. Although Al Share had previously travelled between Egypt and Sudan for work, as his books and articles critiquing Islam gained popularity, he was forced to flee Egypt without completing his studies. Al Share was in his 50s when he immigrated to the United States, seeking ways to further his work as a political author. Despite return trips to continue his political work 
in Sudan, Al Share made steady progress through the ESL course sequence, expressing pride in his "mastery" and "good result" in ESL. He planned to enroll in a degree program in order to continue his Sudanese activism in English: "I am working as a leader," he explained in an early interview, "I insist to take English seriously, to master that language, to write. I am going to write something in English even to my children - to our children in Sudan." In pursuit of this goal, Al Share chose to bypass the remaining ESL courses, as noted earlier, and instead registered for a developmental literacy course.

Al Share's identity as an accomplished student and intellectual manifested in his behaviour inside and outside of the classroom. Unlike Labiba, who saw help-seeking as linked to her identity as "one who persists," Al Share saw working independently as a marker of his educational experience and intellectual ability. Like Labiba, Al Share implemented intensive study routines (e.g., extensive note-taking, translation) developed from his previous academic experiences. Yet despite his past successes, as well as his strong work ethic, Al Share struggled with multiple aspects of his first undergraduate college course in the United States. Although Al Share claimed to invest numerous hours in his studies, his instructor did not see as much progress as she would have liked. One of Al Share's most significant challenges was with technology. He was unfamiliar with the course's digital resources (e.g., the course learning management system, other uses of the internet for academic purposes), which caused him to fall behind. His instructor, Anne, described his issues with the computer as "a nightmare, 'cause a lot of the classes, he just takes the whole time trying to get assignments, and so he'll have worked on them and say, 'I worked on this for eight hours,' and it's not there."

Al Share attended class regularly and was an engaged participant, but his behaviours at times appeared off-task. During one classroom observation, for example, Al Share was supposed to create a PowerPoint presentation on punctuation rules. As described in the first author's observation notes:
$\mathrm{Al}$ Share proudly read through a presentation from a previous class about the need for religious freedom and women's rights in North Sudan. Many of the slides demonstrated his mastery of the concepts he was supposed to be presenting, but Al Share focused solely on the content of his presentation. Al Share then opened several Word documents which revealed pages of text in Arabic-samples of his political writing which he proudly described to me before reluctantly returning to the punctuation rules PowerPoint he was supposed to be creating. (Observation Notes)

This was one of multiple instances in which Al Share spent significant time reviewing his previous work - a behaviour which reaffirmed his purpose for enrolling in college, but which did not assist him in his efforts to complete his developmental literacy assignments. 
Al Share also struggled with course readings-particularly the book Methland (Reding, 2010), about a small midwestern American town's methamphetamine epidemic. He reported spending at least 10 hours reading each chapter of the book (a weekly assignment), but his comprehension seemed low. Anne noted with concern that Al Share seemed to rely heavily on translation devices for reading, and that his journal entries about the book were difficult to follow. For his part, Al Share felt that there were other factors causing his difficulty with the course. He attributed his challenges with Methland to the fact that the text differed considerably from his academic interests and cultural background knowledge, and therefore felt irrelevant. He also noted that the characters' "country language" was quite different from the "educated" (British) English he learned abroad and used as a political activist.

Al Share's writing skills were also a point of concern for Anne. She acknowledged Al Share's experiences as a published author but did not see those experiences as relevant to the college's academic expectations. "I mean he's a writer in his own country, but the hard thing for him is reading and understanding." His first response essay was, she claimed, "mostly plagiarized; it was mostly just copied from the chapter." Al Share at times resisted this narrative, including resenting Anne's efforts to correct his English use: "I know British English, but they [teachers] say is wrong. Yeah, I know is right, but they say is wrong!" This played out frequently in Al Share's responses to the aforementioned Methland text, where he chose to write about complex themes which Anne felt he did not fully comprehend or have the language skills to discuss. For Al Share, taking on challenging themes in the text was a manifestation of his identity as a scholar and intellectual. Anne, however, saw Al Share as "not ready" linguistically for this level of intellectual work. Moreover, the idea that Al Share might know a different form of English seemed irrelevant to Anne, who measured Al Share's work against a (U.S.) native speaker standard. As she continued working with Al Share, Anne began to question whether bypassing ESL to join the developmental literacy course had been the right choice for him. Although she felt that he "got a lot of practice" with using academic language in the course, she saw only a "borderline possible" chance that Al Share would be successful with other credit-bearing coursework at the college.

As the term progressed, Al Share shared more readily in class about his experiences as a published author. However, he continued to receive only cursory affirmations of this identity, such as when Anne requested that he open a previous document he had written about Sudanese politics, only as an example of how to create a new document. As the semester went on, Al Share increasingly sought validation for his identity as a political activist-even exploring pathways other than college that might allow him to achieve his professional goals. When a Michigan-based printing company specializing in Arabic books contacted him, Al Share accepted the publisher's invitation 
to visit and discuss translating his work. Because he was not certain when the flights would be scheduled, Al Share considered not registering for the following term in order to free up his schedule. Ultimately, Al Share enrolled in the next developmental literacy course, but he said he no longer planned to earn a bachelor's degree.

\section{Discussion}

Labiba and Al Share engaged in behaviours that seemed problematic and at times puzzling to college faculty and staff. Our analysis of these cases suggests, however, that these behaviours can and should be read as intentional acts of self-representation-i.e., as efforts to claim identities that were often obscured or ignored within the educational setting. As has been documented in other studies (e.g., Parks, 2000), these students' level of investment in class activities and assignments was tied to their social identities. Norton (2001) explained how such resistance may emerge from students' "position of marginality" (p. 165). In other words, both of these students attempted to draw from other identities when they felt that those identities might increase their agency - and their legitimization - inside the academy. Yet that identity work was at times read too simplistically as lack of cultural adjustment or academic readiness, which led to questions on the part of the instructor about whether these students in fact belonged in developmental literacy (or in the academy itself). Our interpretation does not intend to overlook or downplay the real academic, cultural, and linguistic challenges that these students faced; rather, we wish to shed light on identity dynamics that impacted how students responded to the instruction and resources that were intended to address those challenges (Norton, 2013; Waterstone, 2008).

In contrast with many of the studies discussed earlier, moreover, some of the resistant behaviours we documented may well have been intended to reengage, rather than to distance students from the academic community. When Labiba chose to spend most of her book presentation telling personal stories, she was foregrounding the theme of determination that she knew had cultural cachet in other academic spaces (e.g., the Bridging Lab). Similarly, as Al Share kept returning to his previous political writings, he highlighted his past academic successes (e.g., with PowerPoint presentations) and reminded himself and others of his professional goals.

It is worth noting that these cases were further complicated by contradictory messages students received from college personnel. Labiba was praised in some academic spaces for her drive and persistence, but she was seen as overly aggressive or reliant - and was even questioned about her psychological wellbeing - in others. Although Al Share's instructor believed developmental literacy would serve his educational goals, she could not articulate the linkage between those goals and her own conception of a student who is "college-ready." In both cases, instructors (and other staff, in Labiba's 
case) expressed concerns mostly amongst themselves, only rarely discussing those concerns with the students directly. Thus, as has been suggested by other case studies of resistance (e.g., Curry, 2001; Harklau, 2000; Szabo, 2006), explicit instructor-initiated conversations about students' academic aspirations, expectations, and experiences might have helped instructors to recognize the "identity work" taking place in students' resistance. For resistance to translate into agency, in other words, instructors and scholars must see "students as active agents who are capable of negotiation, departing from the narrow way of treating these students as passive and problematic" (Liu \& Tannacito, 2013, p. 359).

We acknowledge several limitations to this study of adult immigrant student resistance. First, as with all case studies, our findings are limited by the small sample size, as well as the relatively short timeframe of the study. Second, there may be gaps in our assumptions about learners' motivations and about how the resulting behaviours were perceived by the faculty/staff with whom they interacted. We sought to minimize these limits through use of thick, rich description, a carefully documented system of analysis, and member checking of themes, as noted earlier. We further wish to clarify that our analysis is not intended as a critique per se of the observed faculty and staff: In many cases, we concur with the instructor's assessment of the learners' level of preparation for the developmental literacy or subsequent classes. Rather we seek to identify nuances in learners' resistant behaviours in order to suggest alternative explanations linked to the learners' other goals and identities.

\section{Implications}

What implications does this analysis hold for educators working with adult immigrant learners? First, this study reminds us that students' other identities play an important role in their behaviours and can be leveraged productively in the curriculum. Recognizing students' membership in other communities (e.g., single mothers, activists, authors, public intellectuals) helps us better understand their academic goals and behaviours, including instances of resistance. In other words, recognizing resistance as identity work invites us to view those behaviours within the context of students' broader lives, and might be the first step in promoting student agency and enacting more culturally responsive pedagogy. (Shapiro et al., 2016).

These findings also have implications for our understanding of how funds of knowledge (e.g., Moll et al., 1992) function within higher education. While this study recognizes a range of resources that adult immigrant learners bring with them, it also reminds us of the role that educators and educational researchers play in designating certain funds as valuable to students' academic success (Oughton, 2010; Rios-Aguilar et al., 2011). In order to increase the "exchange-value" of their funds of knowledge (Oughton, 2010, 
p. 69), students need to know what is expected of them in our classrooms and at our institutions -i.e., the "rules of the game" (Curry, 2007, p. 294). This is not to say that students should be expected to comply with every norm. Rather, we suggest that college personnel must provide students with enough explicit information about those expectations so that those students can make informed decisions - a crucial aspect of their agency and identity enactment within higher education (Saenkhum, 2016; Shapiro et al., 2016). We can (and should) have critical conversations with students, in fact, about academic norms and expectations. As Waterstone (2008) explained, "We can encourage a critique of the ideological assumptions that undergird academic literacy, acknowledge diverse sources of knowledge (not only academic knowledge), and explore multiple readings or ways of interpreting the world" (p. 65). Doing this critical work helps us to "foster expanded possibilities for all participants" (Waterstone, p. 65).

When resistance does emerge, we need to treat it as a form of agency enactment (Norton \& Toohey, 2011; see also Szabo, 2006). This means seeing resistance as a resource that can both help and hinder students in achieving their goals. In a discussion of "resistance capital," which she defined as "those knowledges and skills fostered through oppositional behaviour that challenges inequality" (p. 80), Yosso (2005) pointed out that while resistance can be a powerful tool for social change, it can sometimes "feed back into the system of subordination" (p. 81). This underscores the importance of explicit conversations with students about when, why, and how they might choose to enact resistance - and do so effectively - in educational settings.

What possibilities does this case suggest in terms of institutional policies, structures, and curriculum design? It is clear from our findings in this case that the hierarchical, remedial focus of these particular ESL and developmental literacy programs contributed to students' feelings of alienation. Labiba and Al Share would likely have had more "buy-in" with a more integrative program structure, such as a corequisite model of instruction, in which ESL or developmental literacy classes are linked to courses in other academic departments (e.g., Belfield et al., 2016; Christensen et al., 2005). These alternative curriculum structures could help to shift the focus away from linguistic remediation and towards academic mediation across the curriculum (Shapiro, 2011).

Even within a more traditional curriculum, instructors could create opportunities for students to foreground their other identities and their academic and professional goals, so as to increase investment and facilitate sense of belonging. ESL and developmental literacy instructors could, for example, build students' institutional knowledge and relationships, through class visits from instructors in other departments (e.g., Tovar, 2015) or assigned interviews with other college personnel about academic expectations and success strategies (e.g., Keefe \& Shi, 2017). Perhaps if Labiba had been given instruction in how to make explicit connections between academic texts 
and her lived experience-e.g., using a text such as They Say, I Say (Graff \& Birkenstein, 2018) - she would have been able to foreground her identity as survivor more effectively in her writing. Similarly, if Al Share could have had an opportunity to write about his professional experiences and aspirations, he might have put greater effort into learning the technologies and other skills necessary for success within a degree program.

Support entities like writing centers can also help to build institutional knowledge and promote the success of adult immigrant students, by making their philosophies and expectations more explicit. This would help students like Labiba to use their services more effectively, and could invite critical conversations among staff about tacit assumptions, including cultural assumptions about which forms of knowledge, learning, and thinking are valued within academic institutions (Cheatle, 2017), as well as the assumption that a nondirective approach is best for all student writers (see Myers [2003] and Salem [2016] for more on this discussion). Further, although computermediated instruction is increasingly popular in developmental education (Coleman et al., 2017) and adult ESL (Khadimally, 2019), research indicates that instructor support plays an essential role (Bonham \& Boylan, 2011). Al Share would have certainly benefited from an explicit conversation about the course management system and how he could access support in using it to achieve academic success in the developmental literacy class and beyond.

This study highlights many possibilities for cocurricular learning and leadership as well: What if Labiba had been invited to explore (or even research) themes such as persistence and resilience? What if she had been given the chance to mentor other students with immigrant/refugee backgrounds? What if Al Share had been encouraged to submit his Arabic writing to a multilingual publication, or was recruited to tutor students taking Arabic classes? What if both students were invited to examine the academic culture at their institution, and to propose changes that would benefit adult immigrant learners - in line with more of a critical English for academic purposes approach (e.g., Benesch, 2001)? How might these opportunities have enriched their learning experience, and that of their peers as well? These are the sorts of questions that educators can ask as they consider how to recognize the identities and funds of knowledge that adult immigrant learners bring to college communities.

\section{Conclusion}

Often, discussions of student agency seem to reinforce a binary between accommodation (i.e., the students must change to fit the institutional norm) and resistance (i.e., the institution must change in response to the students). We hope our analysis helps to deconstruct this binary, offering insights into how practitioners can teach the expectations of the academy while also providing space for students to complicate and critique those expectations- 
including through foregrounding alternative identities that matter to them. Negotiating this delicate balance between accommodation and resistance is neither simple nor easy, yet it is through this complex negotiation that we acknowledge, respect, and cultivate student agency within our academic communities and beyond.

\section{Acknowledgement}

The authors gratefully acknowledge Labiba and Al Share for their willingness to share their experiences transitioning to college. This article also benefited from reviewers' thoughtful feedback.

\section{The Authors}

Emily Suh (Texas State University) applies critical discourse and ethnographic case study methods to explore the intersections of multilingual learners' literacy and language practices in adult education and postsecondary developmental education contexts. Her recent work examines students' studying and classroom engagement as forms of symbolic capital for identity enactment.

Shawna Shapiro (Middlebury College) is an associate professor of writing and linguistics. She researches college transitions and innovative writing pedagogies for international and immigrant/refugee-background students. In addition to peer-reviewed articles (e.g., TESOL Quarterly; the Journal of Language, Identity \& Education), she has published books with TESOL/ NAFSA and Multilingual Matters.

\section{References}

Belfield, C., Jenkins, D., \& Lahr, H. (2016). Is corequisite remediation cost-effective? Early findings from Tennessee. CCRC Research Brief No. 62. New York, NY: Columbia University Teachers College. 10027.212.678.3091

Benesch, S. (2001). Critical English for Academic Purposes: Theory, politics, and practice. New York: Routledge.

Bonham, B. S., \& Boylan, H. R. (2011). Developmental mathematics: Challenges, promising practices, and recent initiatives. Journal of Developmental Education, 34(3), 2-4, 6, 8-10.

Canagarajah, A. S. (1993). Critical ethnography of a Sri Lankan classroom: Ambiguities in student opposition to reproduction through ESOL. TESOL Quarterly, 27(4), 601-626. https://doi. org $/ 10.2307 / 3587398$

Carter, S. J., \& Henrichsen, L. E. (2015). Addressing reticence: The challenge of engaging reluctant adult ESL students. Journal of Adult Education, 44(2), 15-21. https://files.eric.ed.gov/fulltext/ EJ1083975.pdf

Cheatle, J. (2017). Challenging perspectives: Exploring the relationship between ELL students and writing centers. Praxis: A Writing Center Journal, 14(3), 21-31.

Christensen, L., Fitzpatrick, R., Murie, R., \& Zhang, X. (2005). Building voice and developing academic literacy for multilingual students: The commanding English model. In J. L. Higbee, D. B. Lundell, \& D. R. Arendale (Eds.), The general college vision: Integrating intellectual growth, multicultural perspectives, and student development (pp. 155-184).

Coleman, S. L., Skidmore, S. T., \& Martirosyan, N. M. (2017). A review of the literature on online developmental mathematics: Research-based recommendations for practice. The Community College Enterprise, 23(2), 9-26.

Curry, M. J. (2001). Adult ESL students in the contact zone: Exploring the effects of multiple educational attainment levels on the community college writing classroom. Paper presented at the annual 
meeting of the American Educational Research Association. Seattle, WA. https://files.eric. ed.gov/fulltext/ED454706.pdf

Curry, M. J. (2007). Drawing on 'funds of knowledge' to research the 'third spaces' of academic literacies. Journal of Applied Linguistics, 4(1), 125-129. https://doi.org/10.1558/japl.v4i1.125

de Kleine, C., \& Lawton, R. (2015). Meeting the needs of linguistically diverse students at the college level. Oak Creek: The College Reading and Learning Association.

Dumas, J. (2008). The ESL classroom and the queerly shifting sands of learner identity. TESL Canada Journal, 26(1), 1-10. https://doi.org/10.18806/tesl.v26i1.387

Ferris, D., \& Tagg, T. (1996). Academic listening/speaking tasks for ESL students: Problems, suggestions, and implications. TESOL Quarterly, 30(2), 297-320. https://doi. org $/ 10.2307 / 3588145$

Gartman, K. (2016). Transformation of the resistant adult learner. MPAEA Journal of Adult Education, 45(2). http://eds.a.ebscohost.com.libproxy.txstate.edu/eds/pdfviewer/ pdfviewer?vid=1\&sid=1f7f9db9-60d8-4d86-89ce-69b438f71923\%40sdc-v-sessmgr02

Graff, G., \& Birkenstein, C. (2018). "They say / I say": The moves that matter in academic writing (4th ed). New York: Norton, 2009. Print.

Harklau, L. (2000). From the "good kids" to the "worst": Representations of English language learners across educational settings. TESOL Quarterly, 34(1), 35-67. https://doi. org/10.2307/3588096

Harklau, L. (2013). Why Izzie didn't go to college: Choosing work over college as Latina feminism. Teachers College Record, 115(1), 1-32. https://eric.ed.gov/?id=EJ1018102

Keefe, K., \& Shi, L. (2017). An EAP program and students' success at a Canadian University. TESL Canada Journal, 34(2), 1-24. https://doi.org/10.18806/tesl.v34i2.1264

Khadimally, S. (2019). Role of the social constructivist theory, andragogy, and computer-mediated instruction (CMI) in adult ESL learning and teaching environments: How students transform into self-directed learners through mobile technologies. In S. Khadimally (Ed.), Technologyassisted ESL acquisition and development for nontraditional learners (pp. 1-37). Hershey: IGI Global.

Kim, J., \& Duff, P. A. (2012). The language socialization and identity negotiations of generation 1.5 Korean-Canadian university students. TESL Canada Journal, 29(6), 81-102. https://doi. org/10.18806/tesl.v29i0.1111

Leki, I. (1995). Coping strategies of ESL students in writing tasks across the curriculum. TESOL Quarterly, 29(2), 235-260. https://doi.org/10.2307/3587624

Liu, P. H. E., \& Tannacito, D. J. (2013). Resistance by L2 writers: The role of racial and language ideology in imagined community and identity investment. Journal of Second Language Writing, 22(4), 355-373. https://doi.org/10.1016/j.jslw.2013.05.001

McKay, S.-L., \& Wong, S. (1996). Multiple discourses, multiple identities: Investment and agency in second-language learning among Chinese adolescent immigrant students. Harvard Educational Review, 66(3), 577-608. https://eric.ed.gov/?id=EJ530281

Merriam, S. B. (1998). Qualitative research and case study applications in education (2nd ed.). San Francisco, CA: Jossey-Bass.

Merriam, S. B. (2009). Qualitative research: A guide to design and implementation (3rd ed.). San Francisco, CA: Jossey Bass.

Miller, E. R. (2010). Agency in the making: Adult immigrants' accounts of language learning and work. TESOL Quarterly, 44(3), 465-487. https://doi.org/10.5054/tq.2010.226854

Moll, L. C., Amanti, C., Neff, D., \& Gonzalez, N. (1992). Funds of knowledge for teaching: Using a qualitative approach to connect homes and classrooms. Theory into Practice, 31(2), 132-141. http://www.jstor.org/stable/1476399

Myers, S. A. (2003). Reassessing the "proofreading trap": ESL tutoring and writing instruction. The Writing Center Journal, 24(1), 51-67. http://karen.stanley.people.cpcc.edu/docs\%20for\%20 Tips\%20for\%20Writing\%20Center/Proofreading\%20Trap\%20-\%20Myers.pdf

Ngo, B. (2008). Beyond "culture clash" understandings of immigrant experiences. Theory into 
Practice, 47(1), 4-11. https://doi.org/10.1080/00405840701764656

Norton, B. (2001). Nonparticipation, imagined communities and the language classroom. In M. P. Breen (Ed.), Learner contributions to language learning: New directions in research (159-171). New York, NY: Routledge.

Norton, B. (2013). Identity and language learning: Extending the conversation (2nd ed.). Buffalo, NY: Multilingual Matters.

Norton, B., \& Toohey, K. (2011). Identity, learning, and social change. Language Teaching, 44(4), 412-446. https://doi.org/10.1017/S0261444811000309

Ortmeier-Hooper, C. (2008). English may be my second language, but I'm not 'ESL'. College Composition and Communication, 59(3), 389-419. http://academic.brooklyn.cuny.edu/english/ moser/eng\%207506/English\%20may\%20be\%20my\%20second\%20language.pdf

Oughton, H. (2010). Funds of knowledge-A conceptual critique. Studies in the Education of Adults, 42(1), 63-78. https://doi.org/10.1080/02660830.2010.11661589

Parks, S. (2000). Same task, different activities: Issues of investment, identity, and use of strategy. TESL Canada Journal, 17(2), 64-88. https://doi.org/10.18806/tesl.v17i2.890

Paulson, E. J., \& Holschuh, J. P. (2018). College reading. In R. Filppo \& T. W. Bean (Eds.), Handbook of college reading and study strategy research (pp. 27-41). Routledge.

Peirce Norton, B. (1995). Social identity, investment, and language learning. TESOL Quarterly, 29(1), 9-31. https://doi.org/10.2307/3587803

Pennycook, A. (1996). Borrowing others' words: Text, ownership, memory, and plagiarism. TESOL Quarterly, 30(2), 201-230. https://doi.org/10.2307/3588141

Reding, N. (2010). Methland: The death and life of an American small town. New York, NY: Bloomsbury Publishing USA.

Rios Aguilar, C., Kiyama, J. M., Gravitt, M., \& Moll, L. C. (2011). Funds of knowledge for the poor and forms of capital for the rich?: A capital approach to examining funds of knowledge. Theory and Research in Education, 9(2), 163-184. https://doi.org/10.1177/1477878511409776

Rumbaut, R. G. (2004). Ages, life stages, and generational cohorts: Decomposing the immigrant first and second generations in the United States. International Migration Review, 38(3), 1160 1205. https://doi.org/10.1111/j.1747-7379.2004.tb00232.x

Saenkhum, T. (2016). Decisions, agency, and advising: Key issues in the placement of multilingual writers into first-year composition courses. University of Colorado Press.

Salem, L. (2016). Decisions... Decisions: Who Chooses to Use the Writing Center?. The Writing Center Journal, 147-171. https://static1.squarespace.com/static/561fea24e4b0355fd7db67b7/t/ 5a0b6926652dea2f6438af33/1510697254548/Salem\%2C+WCJ\%2C+35.2\%2C+Final+Press+C opy.pdf

Shapiro, S. (2011). Stuck in the remedial rut: Confronting resistance to ESL curriculum reform. Journal of Basic Writing, 30(2), 24-52.

Shapiro, S. (2014). “Words that you said got bigger": English language learners' lived experiences of deficit discourse. Research in the Teaching of English, 48(4), 386-406.

Shapiro, S., Cox, M., Shuck, G., \& Simnitt, E. (2016). Teaching for agency: From appreciating linguistic diversity to empowering student writers. Composition Studies, 44(1), 31-52.

Shapiro, S., \& MacDonald, M. T. (2017). From deficit to asset: Locating discursive resistance in a refugee-background student's written and oral narrative. Journal of Language, Identity $\mathcal{E}$ Education, 16(2), 80-93.

Song, J. (2016). (Il) Legitimate language skills and membership: English teachers' perspectives on early (English) study abroad returnees in EFL classrooms. TESOL Journal, 7(1), 203-226. https://doi.org/10.1002/tesj.203

Suh, E. K. (2017). Off from lost: Generation 1 learners' transition from adult ESL to developmental education. [Doctoral Dissertation]. University of Nebraska. https://digitalcommons.unl.edu/ teachlearnstudent/77/

Suh, E. K. (2018). Counting backwards toward the future of community college immigrant students: Conceptualizing generation 1 learners. Basic Writing e-Journal, 15(1), 1-41. 
Szabo, M. (2006). I meant to say that: How adult language learners construct positive identities through nonstandard language use. TESL Canada Journal, 24(1), 21-39. https://doi. org/10.18806/tesl.v24i1.26

Tovar, E. (2015). The role of faculty, counselors, and support programs on Latino/a community college students' success and intent to persist. Community College Review, 43(1), 46-71. https:// doi.org/10.1177/0091552114553788

Warriner, D. (2004). "The days now is very hard for my family": The negotiation and construction of gendered work identities among newly arrived women refugees. Journal of Language, Identity, and Education, 3(4), 279-294. https://doi.org/10.1207/s15327701jlie0304_4

Waterstone, B. (2008). I hate the ESL idea!: A case study in identity and academic literacy. TESL Canada Journal, 52-67.

White, J. W. (2011). Resistance to classroom participation: Minority students, academic discourse, cultural conflicts, and issues of representation in whole class discussions. Journal of Language, Identity \& Education, 10(4), 250-265. https://doi.org/10.18806/tesl.v26i1.390

Winchester, J. (2013). The potential impact of the teacher on student identities in the classroom in an English language teaching context. TESOL Journal, 4(4), 697-716. https://doi.org/10.1002/ tesj. 492

Yin, R. K. (2014). Case study research: Design and methods (5th ed.). Thousand Oaks, CA: Sage.

Yosso, T. J. (2005). Whose culture has capital? A critical race theory discussion of community cultural wealth. Race, Ethnicity, and Education, 8(1), 69-91. https://doi. org/10.1080/1361332052000341006 